0611

\title{
段ボールの切断加工工程における帯状紙粉発生挙動に及ぼす機械的要因 \\ Mechanical factors on generation behavior of string-like paper dust in cutting process for corrugated board
}

\author{
正 永澤 茂（長岡技大） ○学 金井 慎也（長岡技大・院） 福澤 康（長岡技大） 猿渡 賢一（ISOWA） \\ Shigeru NAGASAWA, Nagaoka University of Technology, 1603-1 Kamitomioka, Nagaoka, Niigata \\ Shinya KANAI, Yasushi FUKUZAWA, ditto \\ Kenichi SAWATARI, ISOWA Corporation, 66 Nishiya-cho, Kasugai, Aichi
}

Key Words: Shearing, Asymmetric blade, Corrugated board

\section{1. 緒言}

段ボールの回転式切断加工時に生じる帯状紙粉は中芯の 重折り部分を切断することで発生することが 2 次元的解析 で明らかにされている ${ }^{[1]}$. Fig. 1 に段ボールの切断モー ドを示す．中芯の変形形状が $\mathrm{M}$ 型， $\mathrm{W}$ 型をとる場合は, 中芯が重折りにならないので帯状紙粉は発生しない。しか し， Z 型となった場合は，中芯が重折りになる変形挙動と なる。上下刃による押込みを更に進めると， Z 型は下段に 示すように 3 種類の形に分類される. $\mathrm{Z}_{\mathrm{C}}$ 型のように中芯を 重折り部分で切る場合, 中芯が脱落し帯状紙粉が発生する. これに対して $\mathrm{Z}_{\mathrm{OV}}$ 型， $\mathrm{Z}_{\mathrm{DR}}$ 型は重折り部分を切らずに済む ので通常は帯状紙粉の発生はないとされている。しかしま た，刃先の滑り，接触抵抗などによって，帯状紙粉が発生 することもある。これに対しての上下刃の切刃先端形状を 変えることにより帯状紙粉の発生が抑制されることがある と経験的に知られている。

本研究では帯状紙粉の発生を抑制する手法を開発するこ とを目的とし, $\mathrm{Z}$ 型変形を抑制するための切刃先端形状の 効果を調べた.
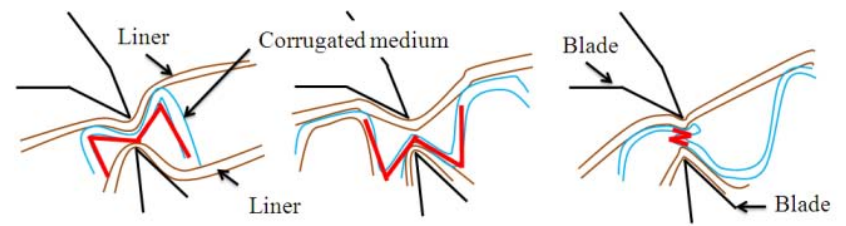

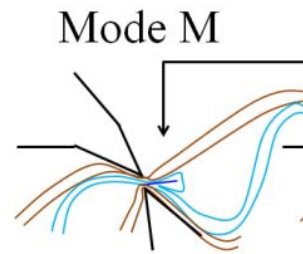

Mode $Z_{\mathrm{OV}}$ Mode W

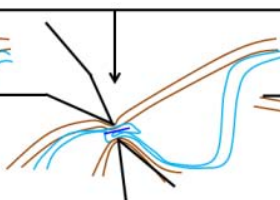

Mode $Z_{\mathrm{C}}$
Mode Z

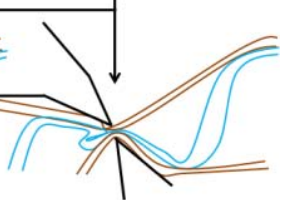

Mode $\mathrm{Z}_{\mathrm{DR}}$
Fig. 1 Classification of deformation mode

\section{2. 実験方法}

Fig. 2(a) に本実験で使用した小型装置の概要を示す. 回転 式切断機における最終切断過程での切刃の回転運動を上下 並進運動で模擬させた.上下非対称な鋼製切刃を (a) の A, Bに取付けた。 下刃に対し試験片を約 $15 \mathrm{~mm}$ 突出させ， 試験片右端をブロックで固定した。切刃はストレート形状 (上刃，下刃)，ノコ刃形状(下刃) 2 つの形状刃に R 掛け加工 をした切刃(両方下刃)を用いた。本研究は次の刃の組合せ を選択して実験を行った。

(1)：ストレートメストレート(上刃 $\times$ 下刃で表記)

(2) : ストレート $\times$ Rストレート
(3) : ノコ $\times \mathrm{R}$ ストレート

(4) : $\mathrm{R}$ ノコ $\times \mathrm{R}$ ストレート

ライナ坪量 $210 \mathrm{~g} / \mathrm{mm}^{2}$, 中芯坪量 $180 \mathrm{~g} / \mathrm{mm}^{2}$ の A フルート試 料を幅 $80 \mathrm{~mm}$, 刃先方向長さ $60 \mathrm{~mm}$ に切り出し, 試験片と した. 試験は試験温度 $276 \mathrm{~K}$, 湿度 $50 \%$ RH の条件で行った。

また，刃先位置による帯状紙粉発生挙動の相違を調べた。 Fig. 2 図(b)に切断位置の模式図を示す. 試験片段頂を刃先 位置になる場合を原点 $X=0$ として段ピッチ $\lambda=8.8 \mathrm{~mm}$ の $X \%$ だけ右側に動かした位置を $\lambda X \times 10^{-2} \mathrm{~mm}$ で記述した.なお, 刃先位置を左側にずらした場合には，負記号で示した。小 型試験機は下刃を固定し，上刃を切込み深さを一定で切断

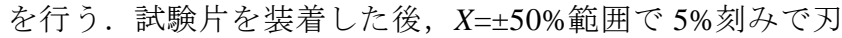
先位置を調節し, 送り速度 $V=0.5 \mathrm{~mm} / \mathrm{s}$ で切断完了するまで 押込み，それぞれの刃先位置 Xにおいて 10 回ずつ切断を 行った。装置正面から CCD カメラにより試験片断面を撮 影し, 押込み過程における中芯の変形挙動を観察した。

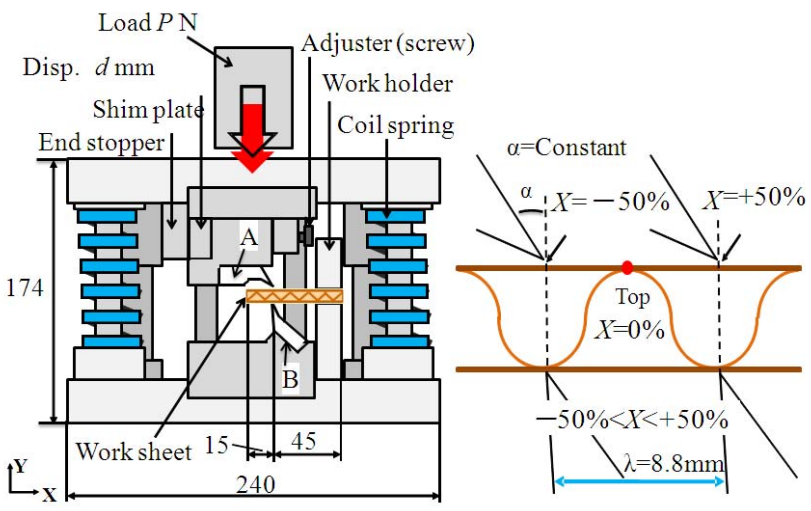

(a) Front view of die set (b) The shape of cutting blade Fig. 2 Schematic diagram of 2 dim shearing apparatus

\section{3. 実験結果及び考察}

前述の切断実験を行うにあたり，予備試験として，上刃で 段頂を押し潰して切断する「山切り」による切断を行い, 刃先隙間を決定した. 刃先隙間を $\mathrm{c}=25 \mu \mathrm{m}, 50 \mu \mathrm{m}, 75 \mu \mathrm{m}$, $100 \mu \mathrm{m}$ における切断実験を行い, 刃先隙間別の押込み比率 $d / t$ と切刃先端形状の関係を Fig. 3 に示す. ここで $t$ : 試験 片厚さ， $d:$ 切刃の押込み量であり,$d / t=1.0$ で上下刃先が 接触する. その結果, 刃先隙間が大きくなると, 刃先間の せん断力が小さくなり, 切断至るまでの押込み比率が高く なる。試験片は片持ち状態なので下刃を支点とし，上刃で 引裂いて破断が起きているのが観察された。また， $\mathrm{R}$ 掛け 刃同士の切断は $d / t$ が大きくなり, 刃先隙間を大きくする と, より顕著になった. 各種の組合せにおいて, $c=25 \mu \mathrm{m}$, $50 \mu \mathrm{m}$ では押込み比率はほとんど変わらないので, 切断実 
験はこの範囲で行えば良いことが分かった。このことから 今回の実験では，上下切刃の剛性や切刃同士の接触を考慮 して, 刃先隙間 $c=50 \mu \mathrm{m}$ で実験を行った.

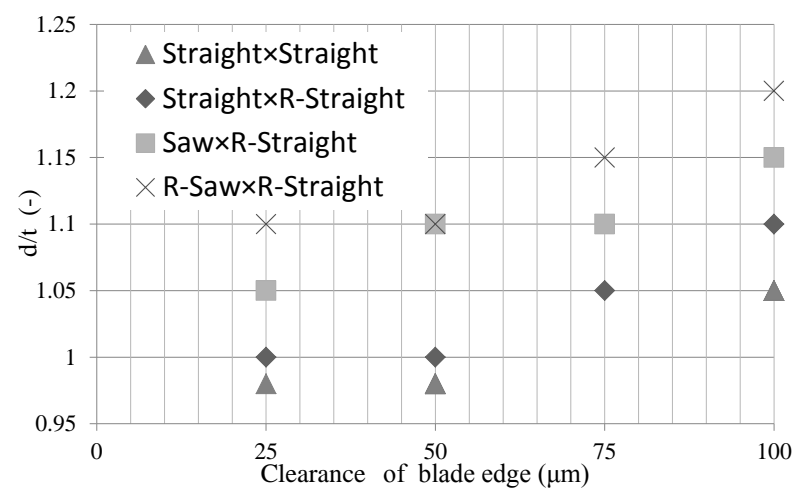

Fig.3 Clearance and different combination of blade indentation

前述した試験方法で，中芯の $\mathrm{Z}$ 型変形での帯状紙粉発生 状況を, $\mathrm{Z}$ 型変形全体と $\mathrm{Z}_{\mathrm{C}}$ 型変形で調べ比較した。 Fig. 4 に刃先位置による $\mathrm{Z}$ 型変形の発生確率の変化 $P_{Z}\left\{Z_{\mathrm{C}}, \mathrm{Z}_{\mathrm{OV}}\right.$, $\mathrm{Z}_{\mathrm{DR}}$ \}を示す. Fig. 5 に $\mathrm{Z}_{\mathrm{C}}$ 型変形の発生確率 $\mathrm{P}_{\mathrm{ZC}}$ を示す. $\mathrm{Z}$ 型は $X=+10 \% \sim+30 \%,-25 \% \sim-40 \%$ の範囲で確認される。こ れに対して, $Z_{C}$ 型変形になるのは正符号で $X=+10 \%$ +20\% と範囲は狭くなった。また, $\mathrm{Z}$ 型変形の発生範囲が左右非 対称の結果になるのは, 中芯の傾斜角度が段頂を中心に左 右に約 $2^{\circ}$ 違うことが影響していると考えられる。このよ うに Z 型変形となる確率は, 切刃先端形状には依存せず, ほぼ同様な確率分布を示した。ただし，発生ピークを示す 刃先位置は $\mathrm{R}$ 刃同士の組合せの場合には，より小さい $10 \%$

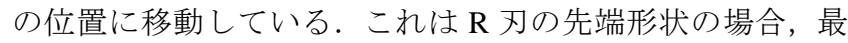
大変形が発生する位置が先端方向の内より変化するためで, 段頂に近い $10 \%$ の方にずれたと考えられる. 刃先位置が負 の場合において，正符号と比較して Z 型の発生確率は 20 30\%下がるが，分布は-35\%を中心として-45 -25\%の範 囲でほぼ左右同様な分布を示した. $\mathrm{Z}_{\mathrm{C}}$ 型の発生確率も $\mathrm{Z}$ 型 の約半分であり，ストレート $\times \mathrm{R}$ ストレートの刃先位置が 若干ずれている。これは正符号の切断と同様に，下刃に $\mathrm{R}$ 刃を用いているためと推定している.

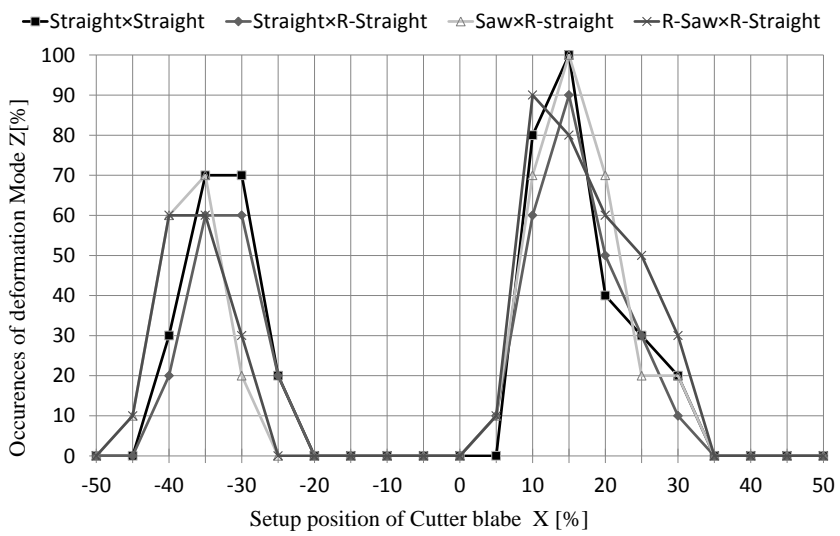

Fig.4 Distribution of deformation mode of $\mathrm{Z}$

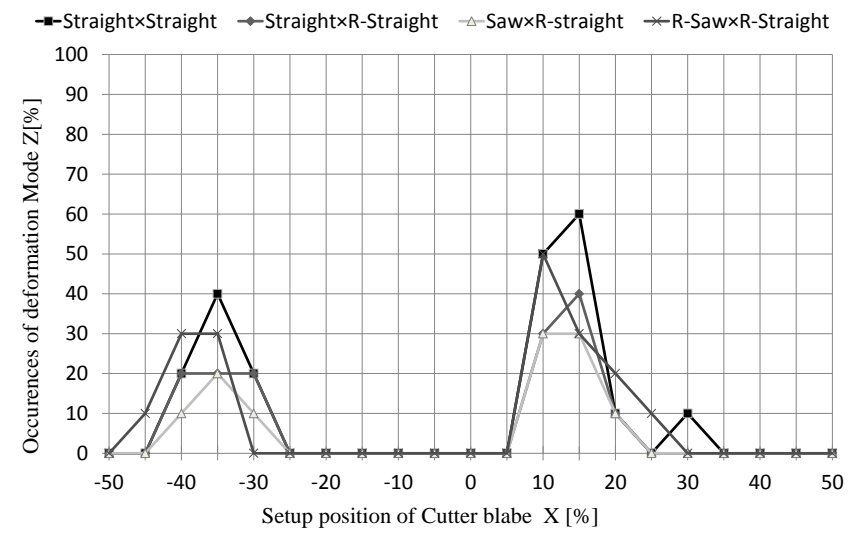

Fig.5 Distribution of deformation mode of Zc

検出された帯状紙粉の切刃先端形状による影響を調べる ために，帯状紙粉の長さを各組合せで計測した．Fig. 6 に 示すように, 帯状紙粉の形状(横断面)は刃先形状より異な るが，ストレート形状のもの，ノコ形状の跡があるものの 2 つに分類できた. 刃先形状の組合せによる帯状紙粉の長 さの測定は採取時に破壊することがあり, 誤差の大きい結 果しか得られていないので，切刃の組合せによる優位性は まだ明らかではない. しかし, 帯状紙粉が刃先形状に切り 出されるため, 切刃など切断におけるパラメータを変える ことにより，帯状紙粉が破壊され，短くなる可能性がある と考えられる.
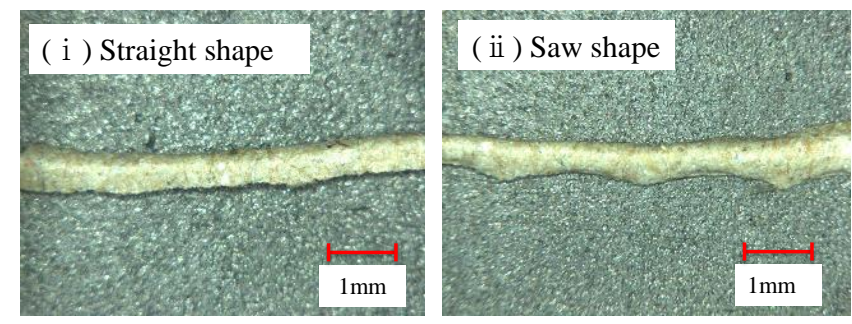

Fig. 6 Typical two types of string-like paper dust

\section{4. 結論}

回転式切断機を簡易的に模擬した小型試験機により A フ ルートの切断実験を異なる切刃先端形状とその組合せによ り試験を行った結果，以下のようなことが分かった.

（1）刃先隙間を小さくすると，切断に至るまでの押込み率 は低くなり， $c=50 \mu \mathrm{m}$ 以下だと漸近する.

(2) Z 型変形の発生確率は, 切刃先端形状には依存せず, 段ピッチにおける刃先位置より決まるが， $\mathrm{Z}_{\mathrm{C}}$ 型の発生確率 は切刃先端形状によって変化する.

(3) 帯状紙粉の切断面は刃先形状に倣った形状になる.

\section{参考文献}

[1] 緒方雄一ら : 段板紙の段筋方向切断における中芯の変 形挙動, 塑性と加工, 52 巻, 610 号, 1213 頁 $\sim 1217$ 頁，（2011） 